\title{
Environmental variability in seagrass meadows: effects of nursery environment cycles on growth and survival in larval red drum Sciaenops ocellatus
}

\author{
Rafael Perez-Dominguez ${ }^{1,2, *}$, Scott A. Holt ${ }^{1}$, G. Joan Holt ${ }^{1}$ \\ ${ }^{1}$ Marine Science Institute, University of Texas at Austin, PO Box 1267, Port Aransas, Texas 78373, USA \\ ${ }^{2}$ Present address: Institute of Estuarine and Coastal Studies (IECS), University of Hull, Hull HU6 7RX, UK
}

\begin{abstract}
In their early larval stages, red drum migrate through coastal inlets and settle into shallow seagrass meadows within estuaries. This study describes environmental rhythms in red drum nursery habitats and evaluates their role in larval growth and survival to determine nursery habitat quality. Well-defined diel cycles were observed in temperature (amplitude 3 to $7^{\circ} \mathrm{C}$ ) and dissolved oxygen (DO) (range 2.9 to $17.5 \mathrm{mg} \mathrm{O}_{2} \mathrm{l}^{-1}$ ), while sporadic cold fronts lowered temperatures by 6 to $10^{\circ} \mathrm{C}$ in 24 to $72 \mathrm{~h}$. Groups of settlement and post-settlement larvae (3.9 to $17.3 \mathrm{~mm}$ standard length) were exposed in the laboratory to cycles of temperature and DO, and to combined temperature and DO diel cycles and then compared to fish grown in constant conditions (control). Relative to controls, growth was significantly reduced only in DO cycles with prolonged daily exposure to hypoxia $\left(>8.2 \mathrm{~h} \mathrm{~d}^{-1}\right)$. Survival was similar in all treatments. In response to water cooling during simulated cold fronts, fish previously exposed to temperature cycles grew faster and had a higher food intake than control fish. Fish exposed to DO cycles maintained a greater food intake than control fish but grew at a similar rate. These results indicate that (1) diel cycles impart a physiological advantage to red drum larvae, (2) field measurements of environmental characteristics at a frequency of once a day may be inadequate for assessing nursery values for red drum, and (3) increased exposure to transient hypoxia in oscillating environmental conditions can affect growth and reduce nursery value and recruitment strength.
\end{abstract}

KEY WORDS: Seagrass $\cdot$ Diel rhythms $\cdot$ Nursery quality $\cdot$ Hypoxia $\cdot$ Fish larvae $\cdot$ Growth $\cdot$ Red drum Sciaenops ocellatus

- Resale or republication not permitted without written consent of the publisher

\section{INTRODUCTION}

Recruitment is an issue central to fish population dynamics. Fish nursery areas are thought to play a critical role in determining adult population size by influencing recruitment success (Underwood \& Fairweather 1989, Sale 1990). Many species of marine fishes exhibit an estuarine-dependent life cycle whereby spawning takes place offshore and recruitment to the estuarine habitat occurs during early life. Rapid larval growth during the extremely vulnerable larval period greatly increases the probability of survival (Pepin 1989, Fuiman \& Magurran 1994, Cowan et al. 1996) and can result in order-of-magnitude changes in recruitment (Houde 1989, 2002).
Structured estuarine habitats can provide a plentiful food supply as well as shelter from predators (Montagna \& Kalke 1992, Rooker et al. 1998a, Stunz \& Minello 2001). However, shallow estuarine habitats may also exhibit substantial fluctuations in environmental parameters such as temperature, dissolved oxygen and salinity (Hubertz \& Cahoon 1999, Robbins $\&$ Bell 2000) to which newly recruited individuals may be exposed. Local variations in temperature, dissolved oxygen (DO) and salinity may be considerable as a result of diel and tidal cycles (Summer et al. 1997, Ziegler \& Benner 1998) and atmospheric frontal systems (fronts) (Brown et al. 2004). Diel variations in temperature of 3 to $5^{\circ} \mathrm{C}$ have been reported for shallow estuarine environments (Beck \& Bruland 2000). Fluctu- 
ations in dissolved oxygen concentrations (DO) may be high in shallow, subtropical, seagrass meadows due to photosynthesis and respiration of benthic communities (Ziegler \& Benner 1998, Beck \& Bruland 2000). Temperature and DO concentrations are possibly the most important abiotic factors controlling growth in aquatic poikilotherms (Fry 1971); therefore diel fluctuations in these factors in seagrass beds during settlement can play an important role in recruitment.

Although the effects of constant temperature and DO concentrations on fish growth and survival have been studied intensively and summarized in numerous reviews (e.g. Fry 1971, Rombough 1988, Blaxter 1992), very few studies have examined the effect of fluctuating diel environmental conditions on fish growth and distribution (Duthie \& Houlihan 1982, Pihl et al. 1991, Diaz \& Rosenberg 1995, Thetmeyer et al. 1999). Taylor \& Miller (2001) reported a reduction in growth of the southern flounder Paralichthys lethostigma exposed to periods of nocturnal hypoxia $\left(2.8 \mathrm{mg} \mathrm{O}_{2} \mathrm{l}^{-1}\right)$. Simulations of juvenile red drum Sciaenops ocellatus growth performance made under time-varying environmental regimes indicate that given an unrestricted food supply, growth may be much faster under diel-cycling regimes than under constant optimal temperature and DO regimes (Neill et al. 2004). Neill et al. (2004) related faster growth under variable conditions to a directive response to low dissolved oxygen concentrations that resulted in an increased metabolic capacity during the normoxic regime. In contrast to the constant environmental conditions in which fishes are typically held in the laboratory, diel cycles of environmental parameters may contain intervals of nearly ideal conditions for growth that compensate for time spent under less optimal conditions. This may result in an overall greater metabolic scope for growth.

Red drum is an economically important, estuarinedependent species commonly found along the Atlantic and Gulf coast of the USA. Red drum spawn in coastal waters of the Gulf of Mexico from late August to October (Peters \& McMichael 1987). Eggs hatch in less than $24 \mathrm{~h}$, and after 2 to $3 \mathrm{wk}$ in the plankton, the larvae settle to seagrass beds and marsh edges within estuaries (Holt et al. 1983, Rooker \& Holt 1997, Rooker et al. 1999, Stunz et al. 2002). In the Aransas Estuary, Texas, seagrass beds serve as settlement and primary nursery habitat for young red drum (Rooker \& Holt 1997, Rooker et al. 1998b). The advanced knowledge of the ecology of this species together with well-established rearing protocols and its economic importance make red drum very suitable for combined field and laboratory studies focusing on sources of recruitment variability in a valuable fishery.

The aim of the present study was 2-fold: (1) to describe the naturally occurring environmental rhythms in temperature and DO (range and patterns of variation) within the red drum nursery habitat during the settlement period, and (2) to simulate these temperature and DO cycles in the laboratory to evaluate their effects on larval growth and survival. This study was part of a larger project aiming to evaluate nursery habitat quality for settlement and to examine factors affecting the recruitment potential of red drum populations.

\section{MATERIALS AND METHODS}

Environmental surveys. Environmental conditions were surveyed at 3 locations in the Aransas Bay system near the Aransas Pass Inlet, Texas, during the fall of 2000 and 2001; 2 stations were located in shallow seagrass beds (SG1 and SG2; Fig. 1). Newly settled Sciaenops ocellatus larvae have been collected previously at these sites (Rooker \& Holt 1997, Rooker et al. 1999, Herzka et al. 2001). A third station (Inlet) was located near Port Aransas in the only inlet linking the estuary to the Gulf of Mexico where planktonic larvae are regularly collected (Holt \& Holt 2000) (Fig. 1). Temperature, $\mathrm{DO}, \mathrm{pH}$, conductivity, turbidity (turbidity in the year 2000 only) and water depth in the seagrass

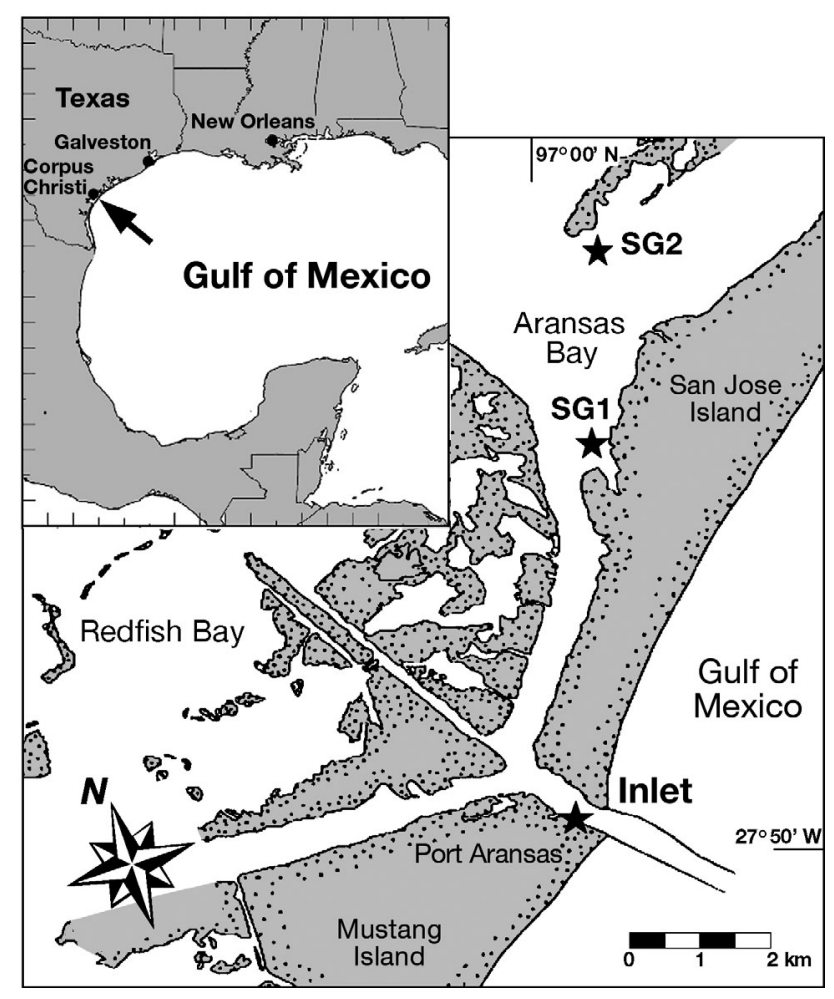

Fig. 1. Study site in Corpus Christi-Aransas Bay system. Arrow indicates general study area on south Texas coast; stars mark location of seagrass meadows (SG1 and 2) and Inlet station studied 
stations were recorded at 15 or $30 \mathrm{~min}$ intervals with multiparameter water quality data sondes (YSI, Ohio) placed within the seagrass canopy. Data from sonde readings were compared with discrete observations made throughout each deployment to assess data quality. Environmental data from the Inlet station, as well as air temperature, were obtained from an automated monitoring system at the Pier Laboratory of the University of Texas Marine Science Institute (UTMSI), which is located in the inlet. All studies coincided with the peak period of larval red drum settlement to seagrass meadows (October and November).

Fine-scale spatial variability in environmental characteristics within a seagrass bed (SG1) was evaluated during the 2001 settlement season. Data sondes were deployed along a transect from the shallowest to the deepest part of the seagrass meadow during 2 separate trips and recovered after 11 and $14 \mathrm{~d}$. In the first deployment, data sondes were placed at the deepest edge and at the shallow flats (the core) of the meadow. The second deployment started 3 d later, whereby a second core and a shallow marsh-edge location were surveyed. Both deployments overlapped in time for $10 \mathrm{~d}$.

Seasonal trends in environmental parameters and the effect and periodicity of atmospheric frontal systems were assessed in 2002 and 2003. Data sondes were deployed continuously at 2 locations within SG1. The sondes were placed toward the deepest edge and the middle of the seagrass meadow for 7 and $11 \mathrm{wk}$ in 2002 and 2003 respectively. Data sondes were checked and data downloaded weekly to ensure proper working condition, calibrate sensors and prevent loss of data.

Rearing and experimental setup. Fertilized eggs were obtained through the manipulation of temperature and photoperiod of captive broodstocks (Arnold 1988) held at the UTMSI Fisheries and Mariculture Laboratory and at the CP\&L Marine Development Center, Texas Parks and Wildlife Department in Corpus Christi. Eggs were sterilized with $0.1 \%$ formalin

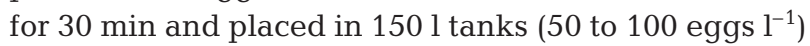
at 26 to $27^{\circ} \mathrm{C}, 27$ to $31 \mathrm{psu}$ in well-aerated, filtered seawater. The tank was put on a flow-through system $\left(25 \mathrm{ml} \mathrm{min}^{-1}\right)$ following stocking of eggs. Only spawns with hatching rates $>95 \%$ were used. Starting $3 \mathrm{~d}$ posthatching (dph), first feeding larvae were provided daily with rotifers enriched with live cultures of Isochrysis galbana (UTEX LB 2307) as well as a formulated larval feed (Kyowa B 250 m; Kyowa Hakko Kogya) (Holt 1993). When larvae reached approximately $3 \mathrm{~mm}$ standard length (SL; 8 to $10 \mathrm{dph}$ ), they were transferred to $350 \mathrm{l}$ flat-bottomed, circular tanks
(20 to 30 larvae $\mathrm{l}^{-1}$ ) equipped with a biological filter. The water-exchange rate was 60 to $120 \mathrm{ml} \mathrm{min}^{-1}$. Larvae were completely weaned onto the formulated feeds 1 to $3 \mathrm{~d}$ after transfer to the larger tanks. Formulated feed of various sizes (Kyowa B, 400 to $1700 \mu \mathrm{m}$ and Proton 2; Inve Aquaculture) as well as frozen brine shrimp Artemia sp. enriched overnight on I. galbana were used to the end of the experiments.

Diel temperature and dissolved oxygen simulations. We evaluated 6 different diel environmental fluctuation treatments derived from the field data independently in 12 different experiments (Table 1). 'Temp1' and 'Temp2' treatments were chosen to reflect low $\left(3^{\circ} \mathrm{C}\right)$ - and high $\left(6^{\circ} \mathrm{C}\right)$-amplitude diel temperature cycles. The 3 oscillating DO treatments (DO1, 2, 3) were designed to mimic various patterns of diel oxygen availability: DO1 was hypoxic-normoxic (low at dawn and normal at noon), DO2 was hypoxichyperoxic (low at dawn and very high at noon), and DO3 was moderate hypoxic-hyperoxic (moderately low at dawn and very high at noon). Finally the 'Cycles' treatment involved simultaneous high amplitude diel temperature and DO3 cycles.

Settlement-size larvae were randomly assigned to six $120 \mathrm{l}$ tanks at a density of approximately 6 larvae $\mathrm{l}^{-1}$ and allowed to acclimate for $24 \mathrm{~h}$. The 6 tanks were then divided into 2 clusters of 3 replicate tanks each. Each cluster was connected to a separate 1501 reservoir to create 2 independent recirculating systems (Fig. 2) for the treatment and control respectively. Only 1 experimental treatment was evaluated at a time. Each experimental treatment was repeated at least twice, except for DO2 and DO3 for which only 1 experiment could be made (see Table 2).

Temperature cycles were imposed using timer-controlled heaters (total of $1500 \mathrm{~W}$ ) and a water chiller (3080 British thermal units $\mathrm{h}^{-1}$ ) connected to the reservoir (Fig. 2). A countercurrent gas-depletion column was placed between the reservoir and experimental 


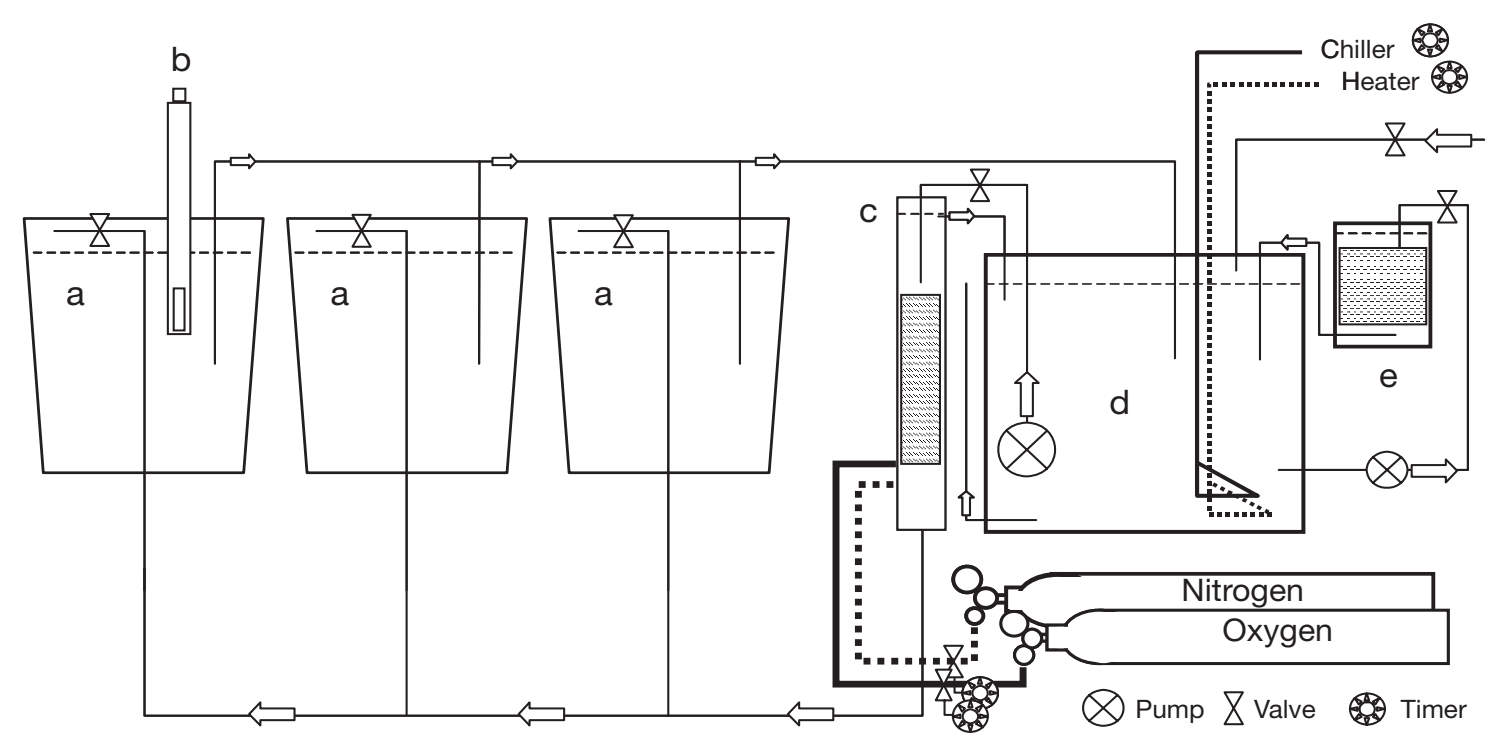

Fig. 2. Experimental recirculating rearing system used to simulate diel temperature and dissolved oxygen environments. a: experimental tank (120 l); b: multiparameter water-quality data logger; c: gas depletion column; d: reservoir (150 l); e: biological filter. Arrows indicate direction of flow. Predictable fluctuating regimens were obtained by trial-and-error manipulations of timer's switching times (cycle timing), and intensity of heat and gas injection (cycle amplitudes)

tanks to generate the desired fluctuating DO conditions (Fig. 2). DO levels were established through the timer-controlled injection of nitrogen or oxygen into the bottom of the column. Water was recirculated through each system 1.2 times $\mathrm{h}^{-1}$. Temperature, DO, $\mathrm{pH}$ and salinity were recorded in at least 1 tank from each recirculating system at 15 or 30 min intervals. Approximately $10 \%$ of the total water volume was exchanged daily. Photoperiod was 12L:12D.

A total of 20 to 25 fish from each tank were sampled immediately before the treatment was started and at the end of each experiment. Some experiments were additionally sampled at regular intervals throughout the experiment duration. All fish were anesthetized with $0.1 \%$ tricaine methanesulfonate (MS222) and their SLs measured from the tip of the snout to the end of the notochord or caudal peduncle. All measurements were made to the closest $0.1 \mathrm{~mm}$ using SigmaScan Pro 4.01.003 (SPSS) image-analysis software.

Cold front simulations. Fish were conditioned to an oscillating temperature or DO environment for approximately 2 wk and then subjected to a simulated strong cold front. To avoid confounding effects of different body size, the conditioning treatments were chosen by identifying the cycling conditions that did not result in growth differences relative to control fish. To simulate the rapid decrease in temperature associated with the onset of a cold front, 3 groups of 18 fish per treatment (DO or temperature-conditioned fish) were transferred to 6 enclosures (height $0.5 \mathrm{~m}$, diameter $0.3 \mathrm{~m}, 700 \mu \mathrm{m}$ mesh) placed within $350 \mathrm{l}$ cylindrical tanks. Water temperature was decreased by $10^{\circ} \mathrm{C}\left(27\right.$ to $\left.17^{\circ} \mathrm{C}\right)$ over a $24 \mathrm{~h}$ period.
Temperature was maintained at 17 to $18^{\circ} \mathrm{C}$ for $2 \mathrm{~d}$, raised to $27^{\circ} \mathrm{C}$ on Day 3 and held at that temperature until the end of the experiment $2 \mathrm{~d}$ later (Day 6 of the experiment). Temperature, DO, salinity and $\mathrm{pH}$ were monitored at 15 to 30 min intervals as described previously. Food levels were adjusted daily to ensure that fish ate to satiation. Every morning all enclosures were carefully siphoned. The particulate food not consumed was collected and dried at $60^{\circ} \mathrm{C}$ for $36 \mathrm{~h}$. Food consumption was estimated by subtracting the food recovered (corrected for leaching using a $24 \mathrm{~h}$ water stability test) from the total amount of food provided. Fish were measured $5 \mathrm{~d}$ before the beginning of the experiment while still in the conditioning tanks, on the day of transfer to the $350 \mathrm{l}$ tanks, at the end of the cold phase, and at the end of the experiment. To minimize handling stress during length measurements, enclosures were lifted partially out of the water and placed in a $0.2 \mathrm{~m}$-deep tray prior to their removal from the tanks. Fish were then quickly anesthetized with MS222 (0.03 $\left.\mathrm{mg} \mathrm{l}^{-1}\right)$, photographed with a reference scale (used for calibration) and returned to a clean enclosure within the tank. Red drum larvae typically recovered from the anesthesia within $1 \mathrm{~min}$. Standard length measurements were performed using ImageJ 1.30v software (http://rsb.info.nih.gov/ij/)

Data analysis. Environmental data: The time series from the environmental surveys were analyzed to determine average daily minimum, maximum and mean values for each parameter. Pearson correlation coefficients were calculated for each time series between observations within the same series at increasing lag intervals over a period of $2 \mathrm{~d}$. Magnitude and direction 
of the autocorrelation changes as the series is shifted down, and the data points being compared drift out of phase and back into phase. This generates a wave-like pattern in which the autocorrelation coefficients oscillate with a periodicity equal to the period of the fluctuation in the time series.

For field data and oscillating DO treatments, the total time spent under hypoxic conditions was calculated to measure the severity of hypoxia experienced by the fish. Jobling (1994) reported limiting oxygen concentrations (LOC) in the range of 50 to $70 \%$ of air saturation for fish. At optimal temperature $\left(28^{\circ} \mathrm{C}\right)$ and with unrestricted food, juvenile red drum start experiencing LOC at $5.0 \mathrm{mg} \mathrm{O}_{2} \mathrm{l}^{-1}$ (73\% air saturation) (Neill et al. 1990, 2004). LOC declines with decreasing temperatures due to the reduced metabolic activity at lower temperatures. At $18^{\circ} \mathrm{C}$, Neill et al. (2004) estimated LOC in the vicinity of $2.0 \mathrm{mg} \mathrm{O}_{2} \mathrm{l}^{-1}$ (43\% air saturation). Miller et al. (2002) reported a DO median lethal dose of $1.8 \mathrm{mg} \mathrm{O}_{2} \mathrm{l}^{-1}$ for red drum larvae held at $29^{\circ} \mathrm{C}$. A temperature-dependent LOC was adopted in this study: $\mathrm{LOC}=2.0 \mathrm{mg} \mathrm{O}_{2} \mathrm{l}^{-1}$ if $\mathrm{T} \leq 18^{\circ} \mathrm{C}, \mathrm{LOC}=-3.4+(0.3 \times \mathrm{T})$ if $18<T<28^{\circ} \mathrm{C}$, $\mathrm{LOC}=5.0 \mathrm{mg} \mathrm{O}_{2} \mathrm{l}^{-1}$ if $T \geq 28^{\circ} \mathrm{C}$. Hypoxia was defined as those DO concentrations below the computed LOC. Salinity and feeding were not factored in these calculations.

Growth and survival data: Temperature differences between treatments and control were taken into account by using effective degree-days (DD eff $_{\text {) }}$ (Fry 1971, Kamler 1992). $\mathrm{DD}_{\text {eff }}$ were calculated by subtracting a threshold temperature (i.e. biological zero, $T_{0}$ ) from the daily average temperature before computing ther-

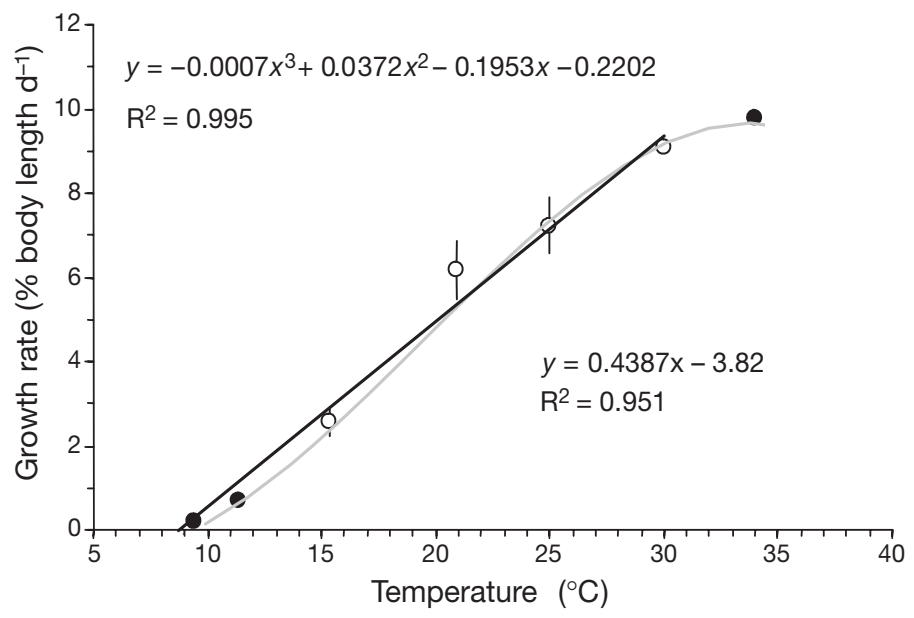

Fig. 3. Sciaenops ocellatus. Larval growth rate (mean $\pm \mathrm{SE}$ ) at different uniform temperature regimes used to estimate species' biological zero (i.e. temperature of no growth, $T_{0}$ ) for effective degree-day calculations. $x$-intercept $\left(T_{0}\right)$ in leastsquares linear regression of growth rate on temperature (black line) was $8.7^{\circ} \mathrm{C}$ regression was fitted only to the central section (O). Gray line is third-order polynomial regression fitted to all data. Regression equations and coefficients are given mal sums. Conceptually, the biological zero represents the temperature at which red drum larvae cease to grow. It can be estimated as the $x$-intercept in the linear regression of growth rate on temperature. To estimate $T_{0}, 2$ groups (3 replicates each) of red drum of approximately $11.0 \mathrm{~mm}$ SL were grown at approximately 5 degree intervals from 9.4 to $34.1^{\circ} \mathrm{C}$. The relative change in growth rate ( $\%$ of initial body size) indicated a decrease at both extremes of the tested temperature range (Fig. 3). Hence, the linear regression was restricted to the growth rates obtained within the linear area of the relationship ( 11 to $\left.30^{\circ} \mathrm{C}\right) . T_{0}$ was $8.7^{\circ} \mathrm{C}\left(\mathrm{R}^{2}=0.95\right)$.

Instantaneous growth coefficients $(\mathrm{G})$ were calculated from an exponential growth model:

$$
\mathrm{G}=\left[\ln \left(\mathrm{SL}_{\mathrm{t}}\right)-\ln \left(\mathrm{SL}_{0}\right)\right] / \mathrm{DD}_{\mathrm{eff}}
$$

where $\mathrm{SL}_{0}$ and $\mathrm{SL}_{\mathrm{t}}$ are the standard lengths at the beginning and end of the testing period, respectively, and $\mathrm{DD}_{\text {eff }}$ represents effective degree-days.

Percent survival (S) was calculated at the end of each trial from the equation:

$$
\mathrm{S}=100\left[\left(\mathrm{~N}_{\mathrm{f}}+\mathrm{N}_{\mathrm{s}}\right) / \mathrm{N}_{0}\right]
$$

where $N_{f}$ is the number of remaining fish in the tank, $\mathrm{N}_{\mathrm{s}}$ is the total number of fish removed through sampling and $\mathrm{N}_{0}$ is the initial number of fish stocked.

We used 2-way analysis of variance (ANOVA) to test for differences in growth and food intake between treated and control fish. Treatment and testing period were used as sources of variation. The interaction term was used to identify treatment differences. If a main effect was detected, the analysis was followed with Tukey's HSD multiple-comparisons test to test for differences between treatment means. Separate Student's $t$-tests were conducted to determine treatment effects on survival. An arcsine transformation was applied to percent survival values before the analysis. In trials where fish were sampled only twice (beginning and end of the experiment), $t$-tests were used to examine differences in growth rate and survival between treated and control fish. In the cold front experiments, repeated-measures ANOVA was employed in the analysis.

All statistical analyses were computed using Systat Version 10.0 software (SPSS) and evaluated at an $\alpha$ of 0.05 .

\section{RESULTS}

\section{Environmental surveys}

Characterization of environmental patterns. In both seagrass study sites, there were similar patterns of environmental fluctuations (Fig. 4). SG1 and 2 showed 


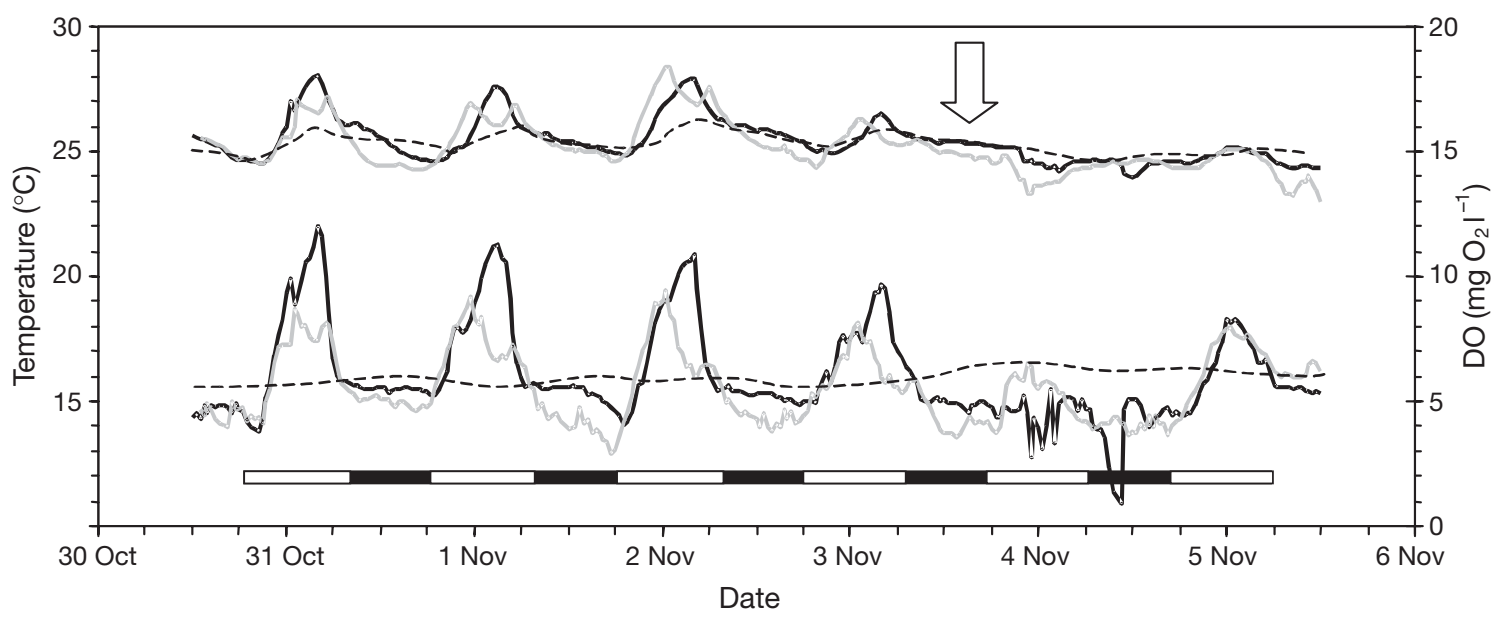

Fig. 4. Temperature (top) and DO (bottom) records for Stns SG1 (black line), SG2 (gray line) and Inlet (dashed line) over sampling period of $6 \mathrm{~d}$ in 2000. Arrow indicates onset of a cold front; horizontal black and white bars represent day and night respectively

well-defined cycles in temperature (amplitude 3 to $7^{\circ} \mathrm{C}$ ), dissolved oxygen (DO) (range 2.0 to $11.2 \mathrm{mg} \mathrm{O}_{2} \mathrm{l}^{-1}$ ) and $\mathrm{pH}$ (range 8.4 to 7.9 ) (Fig. 5). DO levels were high during the daytime and decreased during the night to levels occasionally as low as $2.0 \mathrm{mg} \mathrm{O}_{2} \mathrm{l}^{-1}$. The lowest temperatures and DO levels were generally reached at dawn. The percentage of the day during which conditions were hypoxic varied from 0 to $9.3 \mathrm{~h} \mathrm{~d}^{-1}$ (mean $5.7 \mathrm{~h} \mathrm{~d}^{-1}$ ). For all 3 time series, autocorrelation analysis showed a clear diurnal period of fluctuation, as exemplified by DO in Fig. 6. Daily water depth, turbidity and salinity fluctuations correlated with low-amplitude, mixed, diurnal tides characteristic of the Aransas Estuary, resulting in a time series that oscillated between 12.5 and 25 h (Fig. 6).

Tides were the most prominent periodic feature at the Inlet station. Relative to the patterns observed at SG1 and SG2, the amplitude of temperature cycles was greatly reduced at the Inlet station, with a daily fluctuation range of 1.0 to $1.5^{\circ} \mathrm{C}$ (Fig. 4). Diel DO and $\mathrm{pH}$ cycles were absent in the inlet, with DO levels remaining at saturation levels at all times during the study.

Spatial and temporal environmental variability. The observed daily fluctuations and effect of weather disturbances on monitored environmental parameters were almost identical at the 2 core areas of SG1 and SG2 (Fig. 4). In addition, the data obtained at the shallowest edge of the meadow at SG1 (i.e. the marsh edge) was comparable to that recorded at the core sites. In contrast, there were consistently less fluctuations in the values of the environmental parameters measured at the deep-edge location (Fig. 7).

Sporadic episodes during which temperature decreased by more than $10^{\circ} \mathrm{C}$ within 1 or $2 \mathrm{~d}$ were recorded on several occasions (Fig. 8). These drops in temperature were associated with the passage of winter atmospheric frontal systems (fronts). Shallower
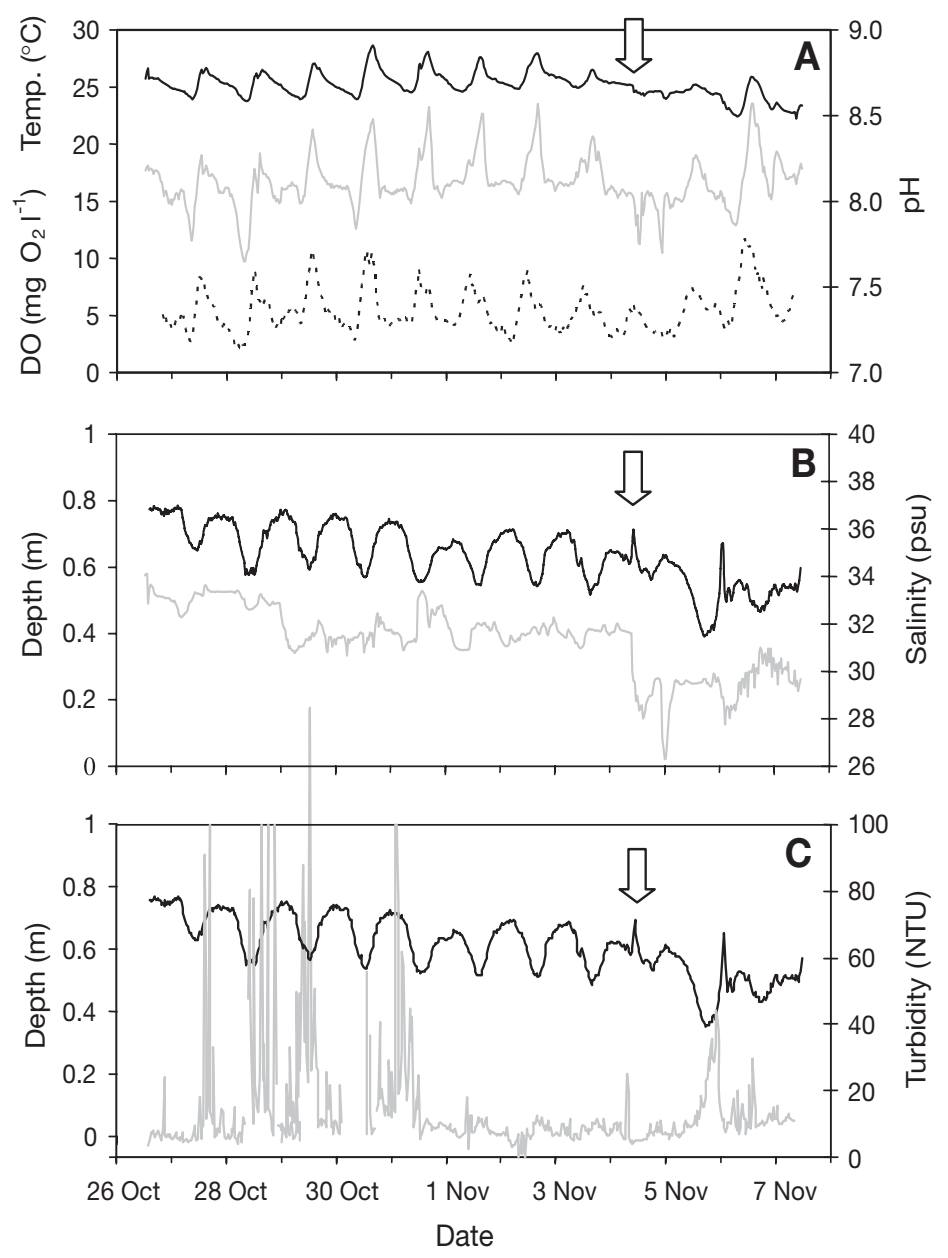

Fig. 5. Sampling time series of water quality records showing daily environmental fluctuations over period of $12 \mathrm{~d}$ in 2000 in seagrass bed SG2. (A) temperature (black line), pH (gray line), and DO (dotted line); (B) water depth (black line), and salinity (gray line); (C) water depth (black line), and turbidity (gray line). Arrows indicate onset of a cold front. NTU = nephelometer turbidity units 


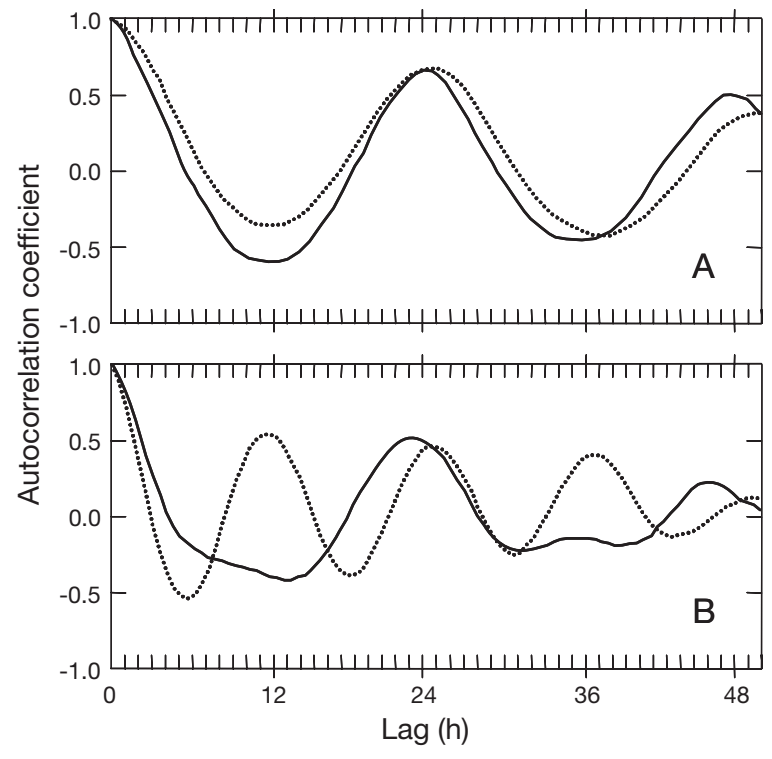

Fig. 6. Autocorrelation plots showing fluctuation period for DO (black line), and depth (dotted line) oscillation in seagrass beds. Data sets corresponding to 2 d sampling-time series from surveys conducted during (A) diurnal and (B) semidiurnal tidal phases

areas often exhibited more drastic decreases in temperature than deep-edge locations (Figs. 7 \& 8). Storm-related disturbances also resulted in irregularities in the tidal fluctuation, and major salinity changes. In 2002, 2 strong tropical storms caused intense runoff that reduced the salinity to 6-8 psu (Fig. 8). Strong fronts were more common toward the end of the settlement season (late October and November; Fig. 8). Weaker fronts resulted in more gradual cooling of the water, but also disrupted the diel patterns of temperature, DO and $\mathrm{pH}$ (examples in Figs. 4, 5, 7 \& 8).

Compared to the shallower sites, hypoxic conditions were greatly reduced or absent at the deep-edge site. Hypoxic conditions ranged from 0 to $14.0 \mathrm{~h}$ (mean $6.3 \mathrm{~h}$ ) of the day at the core and from 0 to $5.0 \mathrm{~h}$ (mean $1.3 \mathrm{~h})$ at the deep-edge location. Episodic events of hypoxia were more likely to occur early in the season during the settlement of new fish in association with higher temperatures and salinities during periods of calm weather (Figs. 8 \& 9). The concurrent presence of red drum larvae during the surveys was confirmed at all 4 sites.

\section{Effects of diel temperature and DO fluctuations}

No differences in growth (in effective degree-days) were detected in the diel cycling temperature treatments (Temp1 and Temp2). However, in cycling DO treatments with prolonged exposure $\left(\geq 8.2 \mathrm{~h} \mathrm{~d}^{-1}\right)$ to hypoxic levels, growth was significantly reduced relative to controls (Table 2). Although activity levels were not evaluated, red drum larvae subjected to low DO levels were visibly less active than control fish at dawn (R. Perez-Dominguez pers. obs.). Supersaturation of DO during the day failed to compensate for the prolonged exposure to hypoxia experienced by fish in the DO2 experiment. No differences were found in the growth rate of the Cycles treatment and their respective controls. There were no significant differences in survival between experimental and control fish for any treatment (Table 2).

\section{Effect of storm-related cooling}

There were no differences in the growth rates of larvae exposed to oscillating temperature or DO and control fish during the conditioning period $(p>0.91)$ (Table 3); however, food consumption was higher for cycle-conditioned fish $(\mathrm{p}<0.01)$ (Table 3$)$. Cooling decreased growth rate and food consumption in all groups.

There was a 2- to 3-fold decrease in growth rate during the cooling phase of the simulated front. Fish previously exposed to temperature cycles had signifi-

Table 2. Sciaenops ocellatus. Effects of various diel-cycling temperature and DO treatments on larval growth. Only 1 experiment could be made for DO2 and DO3. No effects on survival were detected $(p>0.84)$. ${ }^{*}$ Significant difference between control and treatment. $\mathrm{DD}_{\text {eff }}=$ effective degree-days. $\mathrm{SL}=$ standard length

\begin{tabular}{|c|c|c|c|c|c|c|c|}
\hline \multirow[t]{2}{*}{$\begin{array}{l}\text { Treat- } \\
\text { ment }\end{array}$} & \multirow{2}{*}{$\begin{array}{l}\text { Initial } \\
\text { SL } \\
(\mathrm{mm})\end{array}$} & \multirow{2}{*}{$\begin{array}{c}\text { Expt } \\
\text { duration } \\
\text { (d) }\end{array}$} & \multirow{2}{*}{$\begin{array}{c}\text { Hypoxia } \\
\text { duration } \\
\left(\mathrm{h} \mathrm{d}^{-1}\right)\end{array}$} & \multicolumn{2}{|c|}{$\begin{array}{c}\text { Growth rate } \times 10^{-3} \\
\left(\mathrm{DD}_{\mathrm{eff}^{-1}}\right)\end{array}$} & \multirow[t]{2}{*}{$\mathrm{df}$} & \multirow[t]{2}{*}{$\mathrm{p}$} \\
\hline & & & & Control & Cycles & & \\
\hline \multirow[t]{2}{*}{ Temp1 } & 5.0 & 4 & 0 & $9.8 \pm 0.6$ & $9.3 \pm 0.6$ & 4 & $0.966^{\mathrm{a}}$ \\
\hline & 3.9 & 14 & 0 & $2.3 \pm 0.4$ & $2.1 \pm 0.4$ & 25 & $0.314^{b}$ \\
\hline \multirow[t]{2}{*}{ Temp2 } & 4.9 & 14 & 0 & $4.2 \pm 0.3$ & $4.3 \pm 0.1$ & 25 & $0.311^{b}$ \\
\hline & 5.8 & 20 & 0 & $4.8 \pm 0.2$ & $4.9 \pm 0.3$ & 25 & $0.931^{b}$ \\
\hline \multirow[t]{2}{*}{ DO1 } & 4.1 & 23 & 13.9 & $4.8 \pm 0.0$ & $4.3 \pm 0.1^{*}$ & 30 & $0.000^{\mathrm{b}}$ \\
\hline & 4.8 & 13 & 15.7 & $7.3 \pm 0.3$ & $5.6 \pm 0.5^{*}$ & 20 & $0.036^{\mathrm{b}}$ \\
\hline DO2 & 4.6 & 16 & 8.2 & $4.7 \pm 0.3$ & $4.1 \pm 0.2^{*}$ & 30 & $0.016^{\mathrm{b}}$ \\
\hline DO3 & 4.4 & 22 & 6.9 & $4.5 \pm 0.0$ & $4.4 \pm 0.1$ & 30 & $0.628^{\mathrm{b}}$ \\
\hline \multirow[t]{4}{*}{ Cycles } & 5.8 & 8 & 1.9 & $6.1 \pm 0.4$ & $6.7 \pm 0.7$ & 4 & $0.518^{a}$ \\
\hline & 9.6 & 8 & 1.9 & $5.0 \pm 0.1$ & $5.1 \pm 0.2$ & 4 & $0.471^{\mathrm{a}}$ \\
\hline & 11.2 & 11 & 0.5 & $3.2 \pm 0.2$ & $3.1 \pm 0.2$ & 4 & $0.604^{\mathrm{a}}$ \\
\hline & 17.3 & 8 & 6.3 & $3.1 \pm 0.1$ & $3.0 \pm 0.2$ & 4 & $0.618^{\mathrm{a}}$ \\
\hline
\end{tabular}



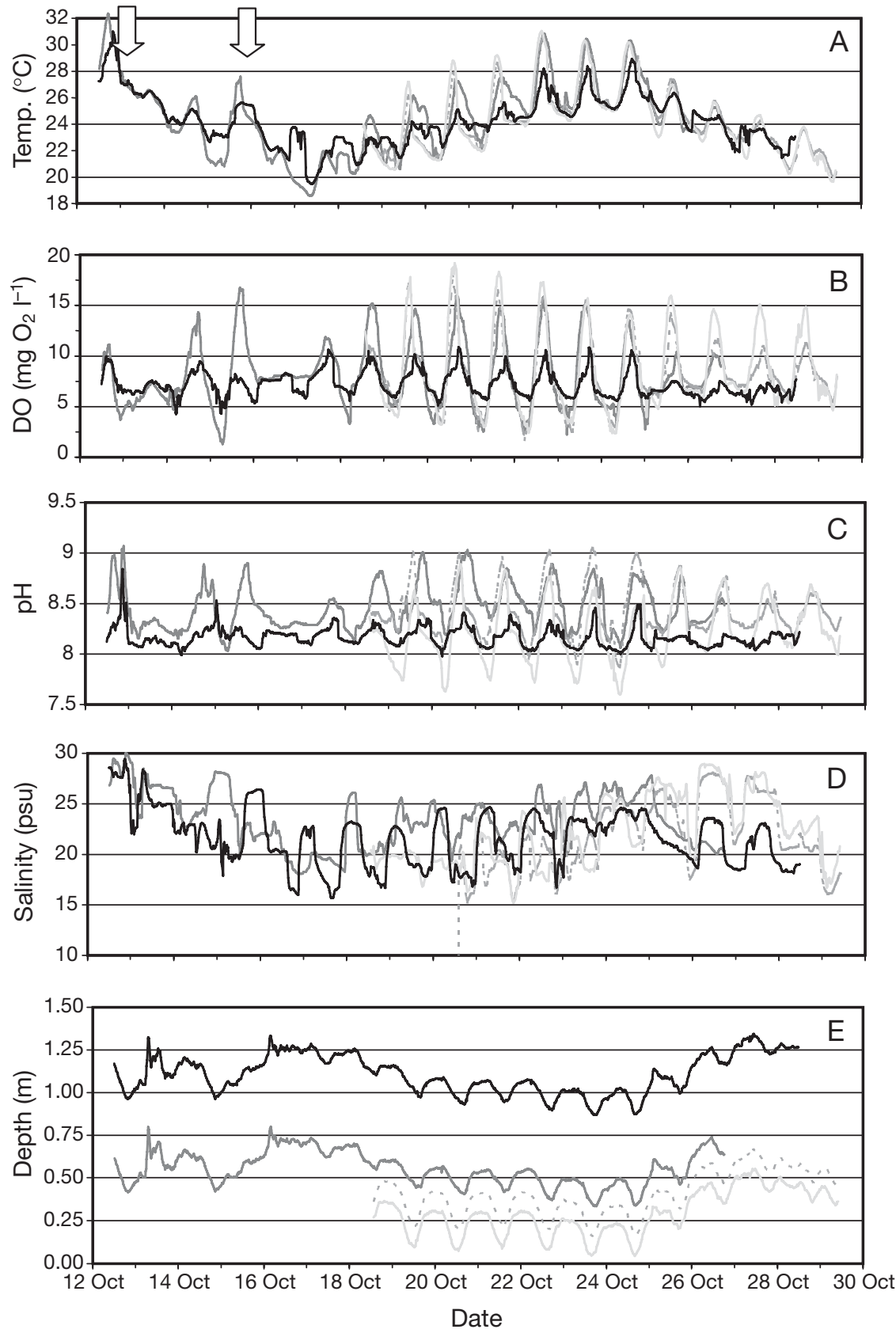

Fig. 7. Water quality records showing spatial variability in environmental variables at deep-edge (black line), Core1 (gray line), Core2 (dotted line) and marsh edge (light-gray line) sites at Stn SG1 in 2001. Arrows indicate onset of cold fronts

cantly faster growth rates during the cooling phase of the front $(\mathrm{p}<0.05)$ than those held at a constant temperature (Table 3). However, the difference in growth rate was no longer apparent during the recovery phase, when the temperature increased to the initial level of $27^{\circ} \mathrm{C}$. On average, food consumption was higher for fish previously grown under cycling temperature conditions than control fish $(p<0.01)$ (Table 3).
Fish conditioned to DO cycles grew at a rate similar to control fish during the simulated cold front (Table 3); however, they exhibited greater food intake ( $p<0.02$ ) throughout the conditioning, cooling and recovery periods (Table 3 ). There was no mortality during these experiments.

\section{DISCUSSION}

Naturally occurring environmental cycles are linked to different patterns of energetic input within the relatively confined nursery habitat. Circadian rhythms arise from day-night and tidal cycles, while meteorological disturbances drive stochastic fluctuations. In shallow, productive seagrass beds, there is extensive primary production (photosynthesis) (Moncreiff et al. 1992, Ziegler \& Benner 1998) and respiration confined to a small volume of water, which can result in large variations in DO concentrations during the course of a $24 \mathrm{~h}$ period. Temperature, DO and $\mathrm{pH}$ cycles were clearly related to insolation. Diel cycles of $\mathrm{pH}$ were small but very consistent, and strongly correlated with DO cycles, confirming the important role of photosynthesis and respiration in the observed diel DO fluctuation.

Fronts usually have a great impact on normal diel fluctuations, since they not only lower water temperature but also affect DO and all other parameters. Turbidity data was intended as a proxy for tidal flushing since incoming waters from offshore would have low turbidity compared to estuarine waters. We expected to see a turbidity maxima associated with the rising tide and salinity changes. However, water movements across shallow seagrass beds were probably influenced by factors like local topography or prevailing winds that were not evaluated, making interpretation of turbidity data very difficult.

In this study, diel temperature and DO cycles were weakened or disappeared during the passage of winter fronts. Strong fronts and tropical storms usually have major impacts on salinity and water level that result in the rapid onset of major water quality 

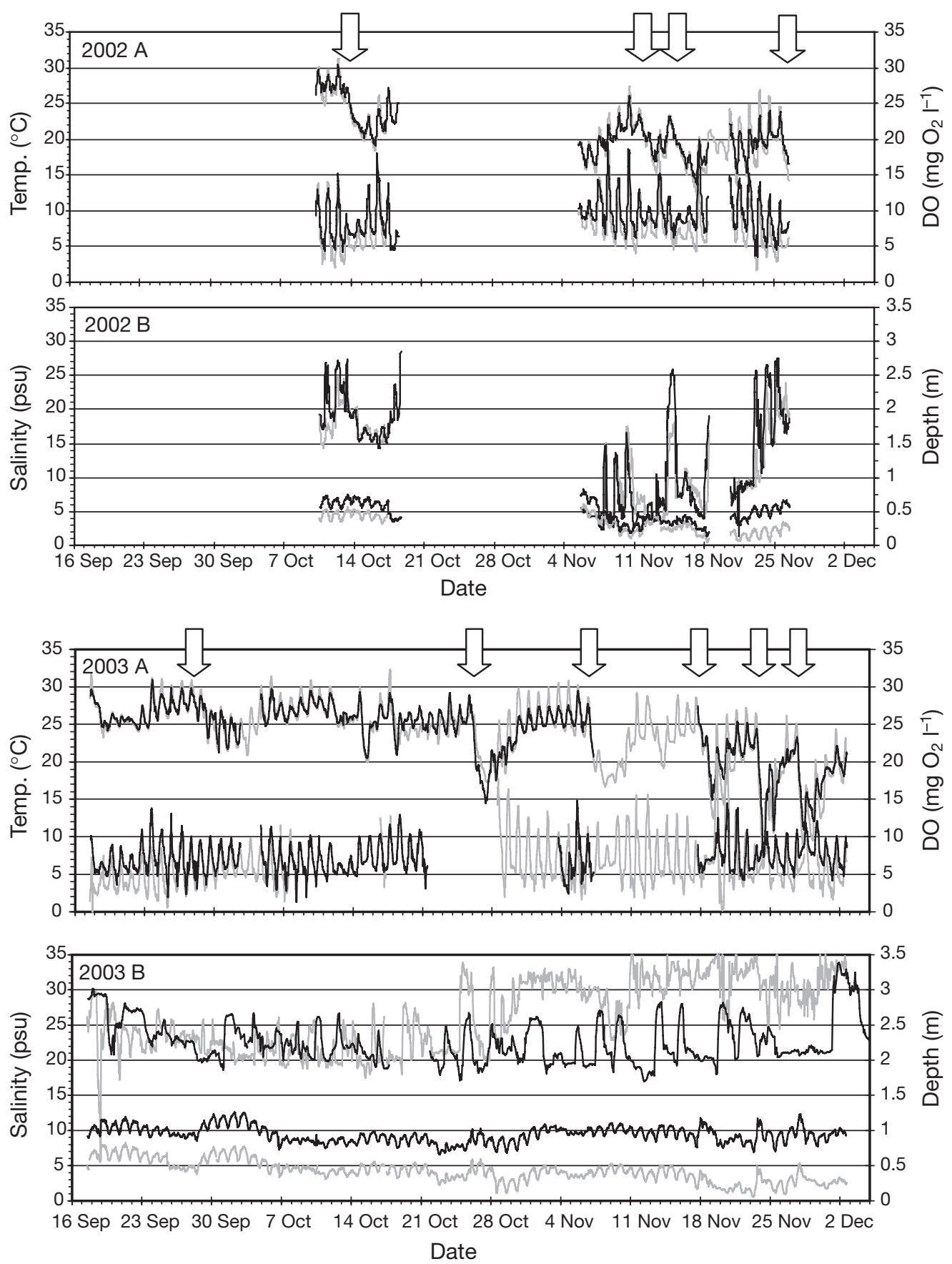

Fig. 8. Water quality records for seagrass deep-edge (black line) and core (gray line) sites at Stn SG1 in 2002 and 2003 during red drum settlement and post-settlement periods. (A) water temperature (top), and DO (bottom); (B) salinity (top), and depth (bottom). Arrows indicate onset of cold fronts

changes. An extreme example occurred in the latter half of 2002 when 2 storms lowered salinity to 6-8 psu. Similarly, late in 2003, 3 consecutive cold fronts caused 3 sudden drops in temperature of about $15^{\circ} \mathrm{C}$ in less than $24 \mathrm{~h}$. These events may result in reduced growth and, in some extreme circumstances, mortality (Breitburg et al. 1994, Houde 2002).
Seagrass meadows were composed of 2 distinct habitats, the deep-edge and the shallow core zone. Deep-edge habitats are substantially more stable than core zones with respect to diel and meteorological forcing. These 2 zones represent the environmental conditions to which red drum larvae might be exposed following settlement. Although there is little informa- 


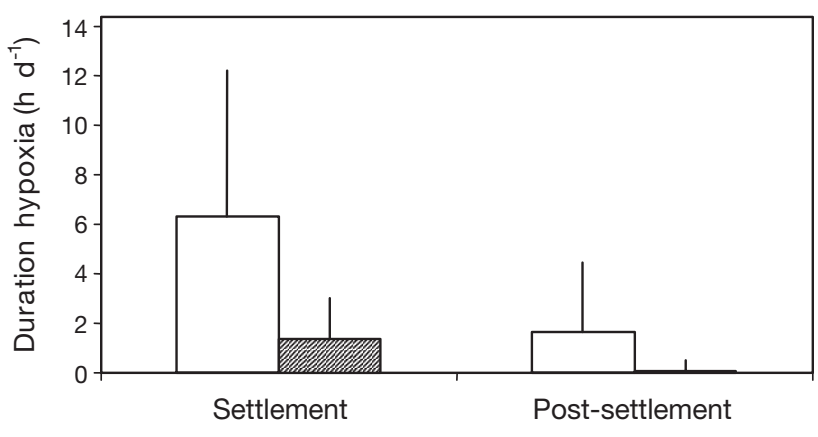

Fig. 9. Relative mean $( \pm \mathrm{SD})$ daily duration of hypoxic events during active settlement period and the post-settlement period in core (open bars) and seagrass edge (gray bars) areas during 2003

tion regarding the fine-scale distribution of newly settled red drum larvae, the deeper edge within a meadow may provide the first adequate nursery habitat encountered by individuals, since the seagrass edge is the first logical contact of new settlers within the nursery. Larvae in the process of leaving the relatively stable pelagic environment may use the deep edges of seagrass meadows as transitional habitat before moving to more environmentally challenging areas (Perez-Dominguez 2004).

Our evaluation of the effects of nursery environment conditions on wild red drum larvae depends on the assumption that the fish remain within the seagrass and are consequently exposed to the nursery conditions during the entire settlement phase. This assumption is supported by the following evidence: (1) field collections in the Aransas Estuary indicate that red drum larvae settle and stay within seagrass meadows (Rooker et al. 1999, Herzka et al. 2002), (2) red drum larvae do not undertake diel movements to and from the core seagrass area (Perez-Dominguez 2004), and (3) in laboratory studies, red drum larvae have affinity for and suffer less predation in structured habitats than in open bottom areas (Rooker et al. 1998a, Stunz \& Minello 2001).

Settlement-sized red drum larvae cultured in the laboratory grew at a wide range of temperatures $\left(10\right.$ to $34^{\circ} \mathrm{C}$, Fig. 3); growth rates increased linearly with temperature between 11 and $30^{\circ} \mathrm{C}$. The temperature range observed during the environmental surveys performed in this study (24 to $32^{\circ} \mathrm{C}$ ) should therefore be conducive to optimal or near optimal growth rates of settled individuals. Moreover, the simulated front experiments suggest that exposure to diel temperature rhythms may impart to the fish some advantage during rapid cooling events compared to fish exposed to more constant environmental conditions. The simulation of the passage of frontal systems resulted in a predictable decrease in growth rate during the cooling phase in all groups evaluated (control and cycle-conditioned). However, the growth rate reduction was significantly less for fish previously exposed to temperature cycles. The lack of similar response in fish conditioned to DO cycles indicates that this response is probably related to diel exposure to transient lower temperatures during conditioning, and can be explained as a thermal acclimation response (Blaxter 1992). All groups, however, showed a similar trend in growth rate during the recovery phase, suggesting that the beneficial effect of diel temperature cycles is short lived, which further supports the acclimation hypothesis. Finally, growth rates during the recovery phase remained low while food intake increased to levels similar to those in the conditioning phase. Hyperphagia is usually involved in the compensatory growth response after a period of growth depression due to reduced food supply or temperature (Nicieza \& Metcalfe 1997, Ali et al. 2003). The results suggest a lag in the onset of the recovery process for growth compared to appetite (Nicieza \& Metcalfe 1997), and that the recovery phase was not sufficiently long to detect changes in growth rates.

Fish exposed to environmentally realistic diel cycles ate, on average, more food than control fish, although they maintained similar overall growth rates. It can be inferred that the cost of growth (i.e. energy used per unit weight gain) was higher in the cycling environment. Herzka \& Holt (2000) found that the isotopic composition of settlement-size red drum changed significantly faster for larvae stocked in cages in the field

Table 3. Sciaenops ocellatus. Instantaneous (mean \pm SE) growth rate and food intake of temperature- and DO-conditioned fish during exposure to simulated cold fronts. Values sharing same superscript are not significantly different $(p>0.05)$. No fish died during cold-front exposure. $\mathrm{DD}_{\text {eff }}=$ effective degree-days. Cond. = conditioning period (days); $\mathrm{p}$-values $=$ testing period $\times$ treatment interaction in a 2-way ANOVA

\begin{tabular}{|c|c|c|c|c|c|c|}
\hline \multirow{2}{*}{$\begin{array}{l}\text { Testing } \\
\text { period }\end{array}$} & \multicolumn{3}{|c|}{ Growth rate $\times 10^{-3}\left(\mathrm{DD}_{\mathrm{eff}}^{-1}\right)$} & \multicolumn{3}{|c|}{ Food intake $\left(\mathrm{mg} \mathrm{g}^{-1} \mathrm{~d}^{-1}\right)$} \\
\hline & Control & Cycles & $\mathrm{p}$ & Control & Cycles & $\mathrm{p}$ \\
\hline Temperature & & & 0.004 & & & 0.265 \\
\hline Cond. (14) & $4.8 \pm 0.1^{\mathrm{a}}$ & $4.9 \pm 0.1^{\mathrm{a}}$ & $\mathrm{df}=15$ & $110.9 \pm 14.9^{\mathrm{a}}$ & $136.6 \pm 6.4^{b}$ & $(\mathrm{df}=30)$ \\
\hline Cooling & $0.7 \pm 0.3^{b}$ & $2.0 \pm 0.3^{\mathrm{c}}$ & & $65.8 \pm 3.8^{\mathrm{c}}$ & $87.1 \pm 5.8^{\mathrm{a}, \mathrm{c}}$ & \\
\hline Recovery & $2.3 \pm 0.4^{\mathrm{c}}$ & $1.5 \pm 0.2^{\mathrm{b}, \mathrm{c}}$ & & $69.7 \pm 3.6^{\mathrm{c}}$ & $109.4 \pm 6.4^{\mathrm{a}}$ & \\
\hline DO & & & 0.879 & & & 0.333 \\
\hline Cond. (13) & $4.8 \pm 0.1^{\mathrm{a}}$ & $4.6 \pm 0.1^{\mathrm{a}}$ & $\mathrm{df}=15$ & $111.6 \pm 20.4^{\mathrm{a}}$ & $162.2 \pm 25.0^{\mathrm{b}}$ & $(\mathrm{df}=35)$ \\
\hline Cooling & $1.8 \pm 0.5^{b}$ & $1.9 \pm 0.8^{\mathrm{b}}$ & & $57.3 \pm 4.8^{\mathrm{c}}$ & $68.2 \pm 4.3^{\mathrm{c}}$ & \\
\hline Recovery & $1.9 \pm 0.6^{b}$ & $1.7 \pm 0.1^{\mathrm{b}}$ & & $104.8 \pm 12.0^{\mathrm{a}}$ & $124.3 \pm 8.9^{\mathrm{a}, \mathrm{b}}$ & \\
\hline
\end{tabular}


than for siblings held in the laboratory, and concluded that metabolic turnover (changes in isotopic composition not explained by growth) was accelerated in the caged fish. Faster metabolic turnover is likely to indicate the joint effects of increased respiration (i.e. metabolic work not related to growth) and protein turnover (Hawkins 1991, Jobling 1994, Houlihan et al. 1995) under the environmental conditions in the nursery. Similarly, fish exposed in the laboratory to diel cycles may have higher fixed metabolic costs or increased activity costs in response to the changing environment, which are expected to narrow the metabolic scope for growth (Fry 1971, Wieser \& Medgyesy 2000), which may result in reduced growth. However, the benefit of evolving a nursery-dependent lifestyle strongly argues for specific tradeoffs and adaptations to meet the environmental challenges of these fluctuating environments. The observed increase in food consumption in the laboratory may be a compensatory response to offset the challenges imposed by environmental fluctuations characteristic of nursery grounds. It would be very interesting to determine in future studies how available energy is translated into growth in environments with important diel components.

For juvenile red drum, DO starts limiting growth at about $5.0 \mathrm{mg} \mathrm{O}_{2} \mathrm{l}^{-1}$ at $28^{\circ} \mathrm{C}$ (approx. $74 \%$ air saturation) (Neill et al. 1990). However, limiting DO sharply declines to about 2.0 to $3.0 \mathrm{mg} \mathrm{O}_{2} \mathrm{l}^{-1}$ at 18 to $21^{\circ} \mathrm{C}$ (Neill et al. 2004). All laboratory DO treatments repeatedly exposed red drum larvae to oxygen tensions below the limiting thresholds (i.e. hypoxia). However, only the treatments in which larvae were subjected to severe limitation of dissolved oxygen (DO1 and DO2) resulted in lower growth rates relative to control fish. Juvenile southern flounder Paralichthys lethostigma experience blood chemistry changes while exposed to episodic hypoxia; however, they must remain in moderate but continuous hypoxia to acclimate to low DO (Taylor \& Miller 2001). It is worthy of note that diurnal hyperoxia did not compensate for the nocturnal hypoxia (DO2) in terms of growth rates. In fishes, hyperoxia causes transient acid-base imbalances (Wood \& LeMoigne 1991) as the fishes hypoventilate. However, there is no evidence in the literature that DO levels above saturation result in significant growth impairment (Caldwell \& Hindshaw 1994, Person-Le Ruyet et al. 2002, Foss et al. 2003). In the present study, the cumulative amount of time that fish were exposed to hypoxia in the laboratory was probably the cause of growth reduction in the laboratory experiments. Our laboratory results suggest that growth is impaired when hypoxic events last for more than $8.2 \mathrm{~h} \mathrm{~d}^{-1}$. Consequently, this value could be a criterion that defines poor nursery habitat quality.

In the relatively pristine seagrass beds studied herein, hypoxia is reached repeatedly, especially at the beginning of the settlement season when temperatures and salinities are relatively high and the weather is relatively stable. However, hypoxic conditions typically last for less than $6.3 \mathrm{~h} \mathrm{~d}^{-1}$ in the core of seagrass meadows and less than $1.3 \mathrm{~h} \mathrm{~d}^{-1}$ at the deepest edge. Consequently, short hypoxic events might not limit the overall growth performance of larval red drum in the nursery habitat. On the other hand, eutrophication from anthropogenic impacts on seagrasses may increase primary production (Bostroem et al. 2002, Deegan 2002), leading to greater changes in DO. Ziegler \& Benner (1998), working in pristine seagrass, reported that diel DO changes were linked to local benthic processes. The strong dependency of DO oscillations on day-night cycles and weather events found in our surveys indicates that DO cycles are essentially driven by local productivity. Consequently, eutrophication could result in prolonged periods of hypoxia. Beck \& Bruland (2000) reported diel DO fluctuations varying from $>250 \%$ saturation to complete anoxia under euthropic conditions in a shallow, tidal salt marsh. This may represent an extreme scenario. However, depending upon the severity of the disturbance, environmental conditions within seagrasses could degrade quickly, thereby increasing the amplitude of DO fluctuation and hypoxia events. These conditions could affect red drum growth and therefore the value of the seagrass as nursery habitat.

This study indicates that field estimates of environmental characteristics based solely upon measurements made once a day are inadequate for predicting fish growth in habitats characterized by marked environmental heterogeneity. For example, since oscillating environmental conditions with severe but transient hypoxia would reduce growth in red drum larvae, then a single daily DO measurement made during the daytime would be insufficient to detect growth-retarding hypoxic periods, and growth potential for the habitat would be overestimated.

At settlement, red drum encounter a new and very dynamic habitat where rapid diel environmental changes are probably too short to induce an immediate acclimation to any particular combination of environmental factors. Red drum larvae may function reasonably well in a range of environmental conditions (Duthie \& Houlihan 1982) and avoid, within certain tolerance limits, costly physiological and behavioral acclimation responses to low DO. However, exposure to diel cycles may trigger general physiological changes that prepare their metabolism for a range of conditions. Since both past experience and present conditions can be important, performance estimates under constant conditions have to be used with caution in predicting responses in fluctuating environments. Larval growth and survival in rapidly fluctuating environments of 
estuaries are crucial factors that may help to explain some aspects of recruitment variability in estuarine dependent species such as red drum.

Acknowledgements. We thank C. Pratt, J. Keller, C. Faulk and M. Fencil for field and laboratory assistance during the study. Comments from Maria C. Alvarez, Sharon Z. Herka and 2 anonymous reviewers greatly improved earlier versions of this manuscript. This research was partially funded by the Sid W. Richardson Foundation, the E. J. Lund and C. Barton fellowships, and a grant to R.P-D. from the Texas Water Resources Institute (TWAR061). This is contribution number 1400 from the University of Texas at Austin Marine Science Institute.

\section{LITERATURE CITED}

Ali M, Nicieza A, Wootton RJ (2003) Compensatory growth in fishes: a response to growth depression. Fish Fish 4: $147-190$

Arnold CR (1988) Controlled year-round spawning of red drum Sciaenops ocellatus in captivity. Contrib Mar Sci 30(Suppl):65-70

Beck NG, Bruland KW (2000) Diel biogeochemical cycling in a hyperventilating shallow estuarine environment. Estuaries 23:177-187

Blaxter JHS (1992) The effect of temperature on larval fishes. Neth J Zool 42:336-357

Bostroem C, Bonsdorff E, Kangas P, Norkko A (2002) Longterm changes of a brackish-water eelgrass (Zostera marina L.) community indicate effects of coastal eutrophication. Estuar Coast Shelf Sci 55:795-804

Breitburg DL, Steinberg N, DuBeau S, Cooksey C, Houde ED (1994) Effects of low dissolved oxygen on predation on estuarine fish larvae. Mar Ecol Prog Ser 104:235-246

Brown CA, Holt SA, Jackson GA, Brooks DA, Holt GJ (2004) Simulating larval supply to estuarine nursery areas: how important are physical processes to the supply of larvae to the Aransas Pass Inlet? Fish Oceanogr 13(3):181-196

Caldwell CA, Hindshaw J (1994) Physiological and hematological response in rainbow trout subjected to supplemental dissolved oxygen in fish culture. Aquaculture 126: 183-193

Cowan JH Jr, Houde DE, Rose KA (1996) Size-dependent vulnerability of marine fish larvae to predation: an individualbased numerical experiment. ICES J Mar Sci 53:23-37

Deegan LA (2002) Lessons learned: the effects of nutrient enrichment on the support of nekton by seagrass and salt marsh ecosystems. Estuaries 25:727-742

Diaz RJ, Rosenberg R (1995) Marine benthic hypoxia: a review of its ecological effects and the behavioural responses of benthic macrofauna. Oceanogr Mar Biol Annu Rev 33:245-303

Duthie GG, Houlihan DF (1982) The effect of single step and fluctuating temperature changes on the oxygen consumption of flounders, Platichthys flesus (L.): lack of temperature adaptation. J Fish Biol 21:215-226

Foss A, Vollen T, Øiestad V (2003) Growth and oxygen consumption in normal and $\mathrm{O}_{2}$ supersaturated water and interactive effects of $\mathrm{O}_{2}$ supersaturation and ammonia on growth in spotted wolffish (Anarhichas minor Olafsen) Aquaculture 224(1-4):105-116

Fry FEJ (1971) The effect of environmental factors on the physiology of fish. In: Hoar WS, Randall DJ, Brett JR (eds)
Fish physiology., Vol VI. Academic Press, New York, p 100-156

Fuiman LA, Magurran AE (1994) Development of predator defenses in fishes. Rev Fish Biol Fish 4:145-183

Hawkins AJS (1991) Protein turnover: a functional appraisal. Funct Ecol 5:222-233

Herzka SZ, Holt GJ (2000) Changes in isotopic composition of red drum (Sciaenops ocellatus) larvae in response to dietary shifts: potential applications to settlement studies. Can J Fish Aquat Sci 57:137-147

Herzka SZ, Holt SA, Holt GJ (2001) Documenting the settlement history of individual fish larvae using stable isotope ratios: model development and validation. J Exp Mar Biol Ecol 265:49-74

Herzka SZ, Holt SA, Holt GJ (2002) Characterization of settlement patterns of red drum Sciaenops ocellatus larvae to estuarine nursery habitat: a stable isotope approach. Mar Ecol Prog Ser 226:143-156

Holt GJ (1993) Feeding larval red drum on microparticulate diets in closed recirculating water system. J World Aquacult Soc 24:225-230

Holt GJ, Holt SA (2000) Vertical distribution and the role of physical processes in the feeding dynamics of two larval sciaenids Sciaenops ocellatus and Cynoscion nebulosus. Mar Ecol Prog Ser 193:181-190

Holt SA, Kitting CL, Arnold CR (1983) Distribution of red drum among different seagrass meadows. Trans Am Fish Soc 112:267-271

Houde ED (1989) Comparative growth, mortality, and energetics of marine fish larvae: temperature and implied latitudinal effects. Fish Bull 87:471-495

Houde ED (2002) Mortality. In: Fuiman LA, Werner RG (eds) Fishery science. The unique contributions of early life stages. Blackwell Science, Oxford, p 64-87

Houlihan DF, Pedersen BH, Steffensen JF, Brechin J (1995) Protein synthesis, growth and energetics in larval herring (Clupea harengus) at different feeding regimes. Fish Physiol Biochem 14:195-208

Hubertz ED, Cahoon LB (1999) Short-term variability of water quality parameters in two shallow estuaries of North Carolina. Estuaries 22:814-823

Jobling M (1994) Fish bioenergetics, Vol 14. Chapman \& Hall, London

Kamler E (1992) Early life history of fish: an energetics approach. Chapman \& Hall, London, p 107-196

Miller DC, Poucher SL, Coiro L (2002) Determination of lethal dissolved oxygen levels for selected marine and estuarine fishes, crustaceans and a bivalve. Mar Biol 140:287-296

Moncreiff CA, Sullivan MJ, Daehnick AE (1992) Primary production dynamics in seagrass beds of Mississippi Sound: the contributions of seagrass, epiphytic algae, sand microflora, and phytoplankton. Mar Ecol Prog Ser 87:161-172

Montagna PA, RD Kalke (1992) The effects of freshwater inflow on meiofaunal and macrofaunal populations in the Guadalupe and Nueces Estuaries, Texas. Estuaries 15: 307-326

Neill WH (1990) Environmental requirements of red drum. In: Chamberlain GW, Miget RJ, Haby MG (eds) Red drum aquaculture. Texas A\&M University Sea Grant College Program, Galveston, p 105-108

Neill WH, Brandes TS, Burke BJ, Craig SR and 11 others (2004) Ecophys. Fish: a simulation model of fish growth in time-varying environmental regimes. Rev Fish Sci 12: 233-288

Nicieza AG, Metcalfe NB (1997) Growth compensation in juvenile Atlantic salmon: responses to depressed temperature and food availability. Ecology 78:2385-2400 
Pepin P (1989) Predation and starvation of larval fish: a numerical experiment of size- and growth-dependant survival. Biol Oceanogr 6:23-44

Perez-Dominguez R (2004) Effects of nursery-environment condition on habitat use, growth, survival and endocrine physiology during larval settlement in the red drum (SCiaenops ocellatus). PhD thesis. The University of Texas at Austin, Austin, TX (also available at www.lib.utexas.edu/ etd/d/2004/perezdominguezr32844/)

Person-Le Ruyet J, Pichavant C, Vacher N, Le Bayon A, Boeuf G (2002) Effects of supersaturation on metabolism and growth in juvenile turbot (Scophthalmus maximus L.). Aquaculture 205:373-383

Peters NJP, McMichael RHJ (1987) Early life history of the red drum Sciaenops ocellatus (Pisces: Sciaenidae) in Tampa Bay, Florida. Estuaries 10:92-107

Pihl L, Baden SP, Diaz RJ (1991) Effects of periodic hypoxia on distribution of demersal fish and crustaceans. Mar Biol 108:349-360

Robbins BD, Bell SS (2000) Dynamics of a subtidal seagrass landscape: seasonal and annual change in relation to water depth. Ecology 81(15):1193-1205

Rombough PJ (1988) Respiratory gas exchange, aerobic metabolism, and effects of hypoxia during early life. In: Hoar WS, Randall DJ (eds) Fish physiology, Vol 11. The physiology of developing fish. Part A. Eggs and larvae. Academic Press, New York, p 59-161

Rooker JR, Holt SA (1997) Utilization of subtropical sea-grass meadows by newly settled red drum (Sciaenops ocellatus): patterns of distribution and growth. Mar Ecol Prog Ser 158:139-149

Rooker, JR, Holt GJ, Holt SA (1998a) Vulnerability of newly settled red drum (Sciaenops ocellatus) to predatory fish: is early-life survival enhanced by seagrass meadows? Mar Biol 131:145-151

Rooker JR, Holt SA, Soto MA, Holt GJ (1998b) Postsettlement patterns of habitat use by sciaenid fishes in subtropical seagrass meadows. Estuaries 21:318-327

Editorial responsibility: Kenneth L. Heck, Jr. (Contributing Editor), Dauphin Island, Alabama, USA
Rooker JR, Holt SA, Holt GJ, Fuiman LA (1999) Spatial and temporal variability in growth, mortality, and recruitment potential of post-settlement red drum (Sciaenops ocellatus) in a subtropical estuary. Fish Bull 97:581-590

Sale PF (1990) Recruitment of marine species: is the bandwagon rolling in the right direction? Trends Ecol Evol 5: $25-27$

Stunz GW, Minello TJ (2001) Habitat-related predation on juvenile wild-caught and hatchery-reared red drum Sciaenops ocellatus (Linnaeus). J Exp Mar Biol Ecol 260: $13-25$

Stunz GW, Minello TJ, Levin PS (2002) Growth of newly settled red drum Sciaenops ocellatus in different estuarine habitat types. Mar Ecol Prog Ser 238:227-236

Summer JK, Weisberg SB, Holland AF, Kou J, Engle VD, Breitberg DL, Diaz RJ (1997) Characterizing dissolved oxygen conditions in estuarine environments. Environ Monit Assess 45:319-328

Taylor JC, Miller JM (2001) Physiological performance of juvenile southern flounder, Paralichthys lethostigma (Jordan and Gilbert, 1884), in chronic and episodic hypoxia. J Exp Mar Biol Ecol 258:195-214

Thetmeyer H, Uwe W, Black KD, Inselmann S, Rosental H (1999) Growth of European sea bass (Dicentrarchus labrax L.) under hypoxic and oscillating oxygen conditions. Aquaculture 174:355-367

Underwood AJ, Fairweather PG (1989) Supply-side ecology and benthic assemblages. Trends Ecol Evol 4(1):16-20

Wieser W, Medgyesy N (2000) Aerobic maximum for growth in the larvae and juvenile of a cyprinid fish, Rutilus rutilus (L.): implications for energy budgeting in small poikilotherms. Funct Ecol 4(2):233-242

Wood CM, LeMoigne J (1991) Intracellular acid-base response to environmental hyperoxia and normoxic recovery in rainbow trout. Respir Physiol 86:91-113

Ziegler S, Benner R (1998) Ecosystem metabolism in a subtropical, seagrass-dominated lagoon. Mar Ecol Prog Ser 173:1-12

Submitted: March 16, 2005; Accepted: November 20, 2005 Proofs received from author(s): August 21, 2006 